ORIGINAL ARTICLE

\title{
Effect of employee worktime control on health: a prospective cohort study
}

\author{
L Ala-Mursula, J Vahtera, J Pentti, M Kivimäki
}

Occup Environ Med 2004;61:254-261. doi: 10.1136/oem.2002.005983

See end of article for authors' affiliations

.....................

Correspondence to: Dr L Ala-Mursula, Researcher, Development and Service Centre of Occupational Health, PO Box 36, FIN-90015 City of Oulu, Finland; Leena. Ala-Mursula@oulu.fi

Accepted 4 April 2003

\begin{abstract}
Aims: To investigate the health effects of employee worktime control.
Methods: Prospective cohort study among 4218 permanent full time municipal employees linking questionnaire data from 1997 and 2000 with sickness absence records from 1997 and 2001 . Worktime control was considered high for the highest tertile in both 1997 and 2000, low for the lowest tertile for both years, and intermediate for all other combinations. Self rated health status, psychological distress, and medically certified periods of sickness absence were used as the health outcomes. Adjustments were made for age, baseline health status, occupational status, marital status, dependent children, and behavioural health risks.

Results: In the follow up, women with a low level of worktime control had a 1.9 times (95\% Cl 1.4 to 2.5) higher odds ratio for poor self rated health, a 1.4 times $(95 \% \mathrm{Cl} 1.1$ to 1.8$)$ higher odds ratio for psychological distress, and a 1.5 times $(95 \% \mathrm{Cl} 1.3$ to 1.7$)$ higher risk of medically certified sickness absences than women with a high level of worktime control. The health effects of worktime control were particularly evident among women with families. Among men, worktime control was not associated with self rated health or distress, but it predicted sickness absences in two subgroups: those with dependent children and those with manual occupations.

Conclusions: A low level of worktime control increases the risk of future health problems. The risk is highest among women, especially those with families, and among manual workers. The results suggest that worktime control can help workers integrate their work and private lives successfully.
\end{abstract}

A lthough job control, intrinsic to work, has convincingly been shown to be one of the strongest psychosocial predictors of health ${ }^{1-7}$ much less is known about the health effects of other aspects of control, ${ }^{8}$ for example, control over worktime-that is, autonomy with regard to worktime (worker control over the duration, position, and distribution of his/her worktime). ${ }^{10}$ Worktime control may contribute to the successful integration of work and private lives and thus reduce stress due to conflicting demands from paid work and unpaid domestic work. At the same time, worktime control may even be beneficial within the workplace in that it enables workers to adjust their work hours to prevailing resources.

A recent meta-analysis has linked flexible scheduling, control over the beginning and end of a workday, with lower absenteeism. ${ }^{11}$ Low control of worktime at the occupational level (an ecological measure) has been linked with an increased risk of hospitalisation and cardiovascular disease. ${ }^{12}{ }^{13}$ A recent cross sectional study showed an association between perceived low worktime control and poor health among women, but not among men. ${ }^{14}$ The association was independent of job control, and had the same size of effect as that of job control.

The aim of this prospective study was to explore the health effects of repeatedly measured levels of worktime control. We used three outcomes of health, self rated health status and psychological distress from questionnaires, and medically certified sickness absences from employers' registers.

\section{METHODS}

\section{Participants and design}

Data were drawn from the ongoing Finnish Ten Town Study, which is exploring the health of municipal employees in Finland. ${ }^{15}$ The study began in 1997 in eight towns (Turku, Vantaa, Oulu, Raisio, Naantali, Valkeakoski, Nokia, and
Virrat), the setting of this study. The participants were the 4218 identifiable permanent full-time employees (903 men, 3315 women) who responded to two consecutive surveys, in 1997 and 2000, assessing worktime control, health, and behavioural health risks. The mean age in 1997 was 45.7 (SD 7.7) years for the men and 44.7 (SD 7.4) for women. Of the respondents 186 were managers (55\% women), 1345 were professionals (79\% women), 942 were associate professionals (85\% women), 406 were clerks (95\% women), 558 were service workers (94\% women), 445 worked in elementary occupations ( $72 \%$ women), and 213 worked in other occupations; for 123 respondents the data on occupation were missing. The response rate was $67 \%$ in the baseline survey and $81 \%$ in the follow up. Data on sickness absences were obtained from the employers' records for the periods l January 1997 to 31 December 1997 and I January 2001 to 31 December 2001. The study was approved by the Ethics Committee of the Finnish Institute of Occupational Health.

\section{Worktime control}

The measure of worktime control included employees' perceived control over the beginning and end of a workday, their opportunities to take breaks and to deal with private matters during the workday, the scope for influencing the scheduling of shifts, the scheduling of paid days off and vacations, and the opportunities to take unpaid leave. The six items covered the worktime control elements contained in the regulations of municipal labour contracts. Responses to each item were given on a five point scale $(1=$ very little, $\ldots$, $5=$ very much). The mean of the six items was used. The measure had good internal consistency, with a Cronbach's alpha of 0.82 . A more detailed description of the measure has been published elsewhere. ${ }^{14}$

The scores for worktime control in the 1997 and 2000 surveys were first divided into tertiles, according to tertiles in 
Main messages

- Low control over working time increases the risk of future health problems.

- The risk is highest among women, especially those with families, and among manual workers.

1997. The levels of worktime control were then classified into the following three categories: high worktime control (high in both 1997 and 2000), low worktime control (low at both times), and intermediate worktime control (all other combinations of worktime control levels in 1997 and 2000).

\section{Health}

Self rated health status was assessed by an overall rating of health on a five point scale $(1=$ good, 2 =fairly good, 3 =average, $4=$ fairly poor, $5=$ poor). The responses were dichotomised, 1-2 indicating good health and 3-5 representing poor health. Self rated health is a widely used concept in medical, epidemiological, and health psychological research. ${ }^{16-18}$ In the study cohort, 304 men (34\% of men) and 1140 women (35\%) had poor health at the time of follow up.

Psychological distress was measured by the 12 item version of Goldberg's General Health Questionnaire (GHQ-12), which was developed to screen for non-specific psychiatric morbidity in populations. ${ }^{19}$ To indicate psychological distress, we used the cut off point of at least four of the assessed psychological symptoms being reported more than usual, as in studies validating the GHQ-12 against standardised psychiatric interviews. ${ }^{20}$ In the follow up, 234 men $(26 \%)$ and 947 women (29\%) showed psychological distress.

Sickness absences were measured by the frequencies of medically certified ( $>3$ days) sickness absence periods in 2001. This type of measure has been shown to adequately reflect employee health in epidemiological studies. ${ }^{21}{ }^{22}$ For each respondent, we calculated the days at work during the year by excluding the days absent for reasons other than sickness. These person-years represented "days at risk for sickness absence" and were weighted in the statistical analyses. Employers participating in the Ten Town Study routinely record each sick leave period for every employee, including the dates when each period started and ended. Records were checked for inconsistencies. Overlapping and consecutive periods were combined. According to the regulations, each sick leave certificate must be forwarded for recording. Municipal employers keep strict records of all sick leave in order to receive statutory compensation from the Finnish Social Insurance Institution for salary losses from sick leaves longer than 10 days. The employees on sick leave receive full salary from the first day. Medical certificates are required for sick leaves longer than three days, a focus of this study. Maternity leave and absence from work to care for a sick child are not included in the figures. In Finland municipal labour contracts allow employees to be absent from work for up to three days without loss of salary to care for acutely ill children under 10 years of age, and there are no limitations on the annual number of such absences. Other absences to care for a sick child are not compensated for. In our baseline study ${ }^{14}$ the employees with dependent children did not have any excess of medically certified sickness absences compared with those without children at home. Thus a false use of sickness absence when in fact looking after a sick child appears unlikely.
Policy implications

- Worktime is in transition in Western societies.

- Providing employees with worktime control may buffer against health problems.

\section{Other predictors of health}

Other potential predictors of health included demographic factors (gender, age, occupational status, family characteristics) and behavioural health risks in 1997, as well as baseline health in terms of self rated health status, psychological distress, and the occurrence of medically certified sickness absences (yes versus no). The occupational titles, expressed as the five digit codes of Statistics Finland, were obtained from the employers' records, and occupational status was classified as manual or non-manual work. ${ }^{23}$ Of the family characteristics, we recorded marital status (married or cohabiting versus single, divorced, or widowed) and children under 18 years of age living at home (yes versus no). The behavioural health risks measured were smoking status (current smokers and non-smokers), high alcohol consumption (more than $210 \mathrm{~g}$ of alcohol per week), ${ }^{24} 25$ sedentary lifestyle (less than 30 minutes of fast walking per week), ${ }^{26}$ and overweight (body mass index $>27 \mathrm{~kg} / \mathrm{m}^{2}$ ).

\section{Statistical analyses}

We tested the associations of worktime control (mean scores in 1997 and 2000) with gender and time and their interaction by repeated measures analysis of variance. The baseline differences in the worktime control scores between the study cohort and the dropouts were studied by analysis of variance.

In studying the associations between levels of worktime control in 1997-2000 and other predictors of health, an analysis of variance was used for the continuous variable of age, and $\chi^{2}$ tests were used for the categorical variables (gender, occupational status, marital status, and existence of dependent children). The associations between baseline health status and worktime control at the time of the follow up (reversed causalities) were studied by analysis of variance.

Logistic regression models were used to analyse the associations of worktime control categories with self rated health and psychological distress, and Poisson regression models were used to analyse the associations with sickness absence rates per person years. Use of the Poisson model implies that the between employee variance in the rates of sick leave equals the expected rate. In our study, the dispersion of sick leaves did not significantly deviate from the assumptions of the Poisson models. The analyses were performed both unadjusted and adjusted for demographics (age, occupational status, marital status, and existence of dependent children), behavioural health risks (smoking, alcohol consumption, overweight, and sedentary lifestyle), and the baseline (1997) level of each health outcome.

To study further the effects of worktime control according to the baseline health status, the analyses were replicated for the initially healthy subpopulations: among those with good self rated health in the baseline questionnaire (607 men, 2320 women), no psychological distress (681 men, 2537 women), or no sickness absence in 1997 (614 men, 1991 women), as well as for their counterparts, the initially unhealthy subpopulations. Finally, subgroup analyses were performed according to the occupational, marital, and family status.

All the aforementioned analyses were carried out separately for the men and women. The interactions of gender and of occupational, marital, or family status with worktime 


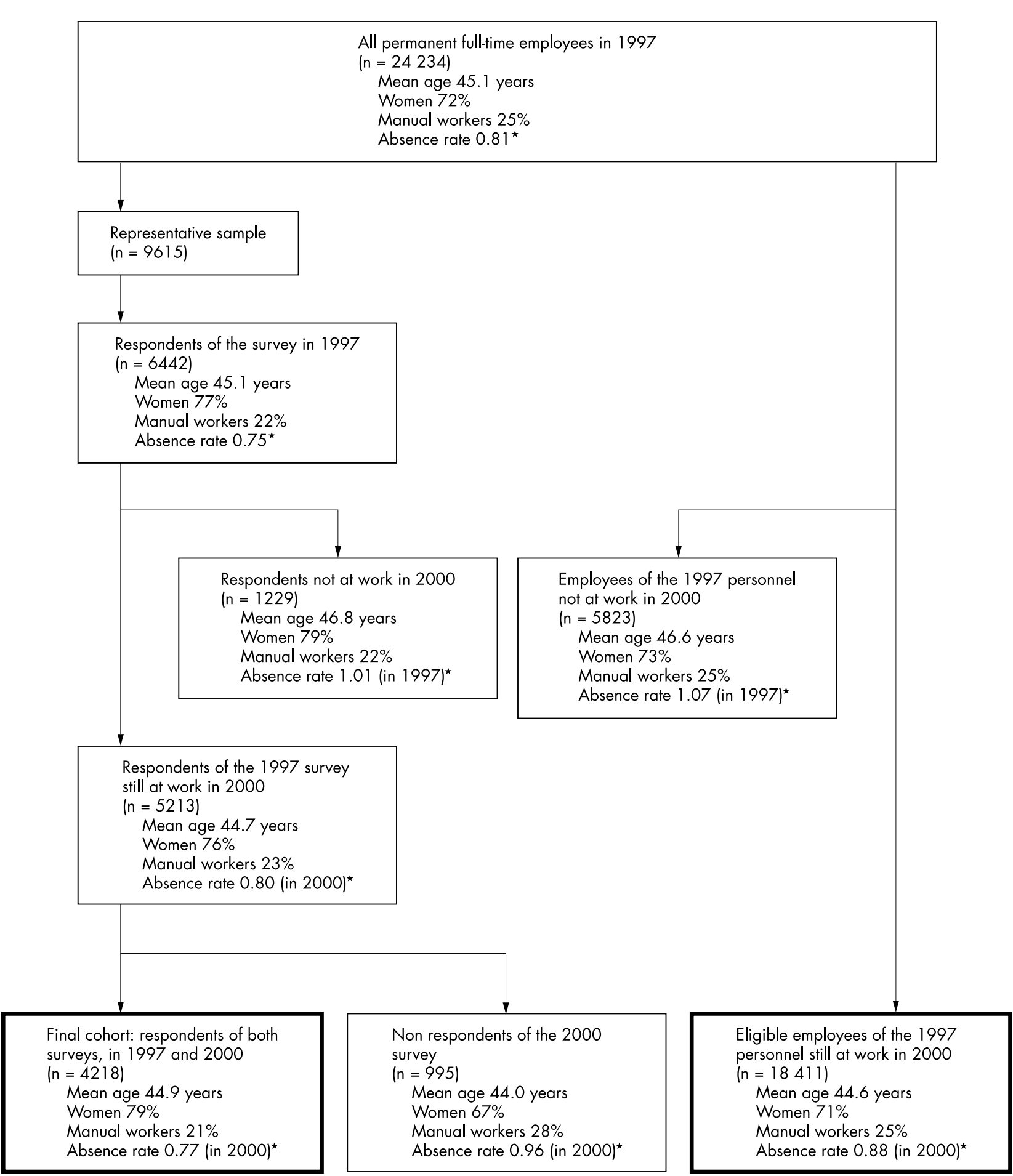

Figure 1 Sample attrition over the period of study, giving the register based demographics of the respondents, non-respondents, and the eligible population. *Absence rate: number of medically certified ( $>3$ days) periods of sickness absences per person years.

control were tested using the corresponding cross product terms. We used the SAS 8.2 program package ${ }^{27}$ for all the analyses.

\section{RESULTS}

Sample attrition is illustrated in fig 1 . Among the participants, women and non-manual workers were somewhat overrepresented, and the rate of sickness absence was lower in comparison with that of the eligible population (that is, all employees of the 1997 personnel still at work in 2000). Among the dropouts, irrespective of gender, the mean age and rate of absence were higher than among the participants and the baseline scores of worktime control were lower among the female dropouts. The repeated measures analyses of variance showed that the mean scores for worktime control in 1997 and 2000 were lower for the women than for the men $(\mathrm{p}<0.001)$, and that there was a declining trend in worktime control over time $(p<0.001)$ that was stronger among the women than among the men $(p<0.001$ for interaction) (table 1).

Table 2 shows the descriptive statistics by the levels of worktime control in 1997-2000. Women were underrepresented 
Table 1 Means (standard errors of the mean) of the worktime control scores in 1997 and 2000 and comparison of the baseline scores between the participants and dropouts

\begin{tabular}{|c|c|c|c|c|}
\hline \multirow[b]{2}{*}{ Sex } & \multicolumn{2}{|l|}{ Participants } & \multirow{2}{*}{$\begin{array}{l}\text { Dropouts } \\
1997\end{array}$} & \multirow{2}{*}{$\begin{array}{l}\text { p for difference* } \\
\text { between } \\
\text { participants and } \\
\text { dropouts in } 1997\end{array}$} \\
\hline & 1997 & 2000 & & \\
\hline Men & $2.89(0.03)$ & $2.82(0.03)$ & $2.74(0.06)$ & 0.24 \\
\hline Women & $2.83(0.02)$ & $2.68(0.02)$ & $2.63(0.03)$ & $<0.001$ \\
\hline
\end{tabular}

*Age adjusted analysis of variance.

among those with continuously high worktime control, and in this group the women were younger than the men. Manual workers of both genders had a high level of worktime control less often than non-manual workers did. In no case was the baseline health status associated with worktime control in the follow up (data not shown).

Table 3 presents the associations between levels of worktime control in 1997-2000 and health status in the follow up. The odds ratios of the women with a low level of worktime control were twice as high for self rated poor health and 1.5 times higher for psychological distress than those of the women with a high level of worktime control. Similarly, women with a low level of worktime control had a 1.5 times higher risk of subsequent medically certified sickness absences. These unadjusted associations remained after adjustment for age, occupational status, marital status, dependent children, baseline level of each health indicator, and behavioural health risks (including smoking, alcohol consumption, overweight, and sedentary lifestyle). Among the men, the levels of worktime control were not associated with health status after the aforementioned adjustments.

Table 4 shows the associations between worktime control and prospective health by the levels of baseline health status. Among the initially healthy women, those with low worktime control had a 1.9 times higher odds ratio for poor self rated health and psychological distress in the follow up, and a 1.3 times higher risk for subsequent sickness absences than those with high worktime control. Among the initially unhealthy women, the associations of low worktime control with poor self rated health and sickness absences in the follow up were even greater. For the either initially healthy or unhealthy men, no significant associations were found between the health outcomes and worktime control.

The interaction analyses showed that the effect of worktime control on self rated health was dependent on gender ( $p=0.043$ for interaction in the adjusted model). An interaction with gender also appeared for psychological distress in the unadjusted model $(p=0.041)$, although it was non-significant when adjusted for baseline distress and other confounders. However, for the incidence of psychological distress among those not distressed at baseline, the effect of worktime control significantly depended on gender $(p=0.032)$. In the total sample, gender interaction with worktime control was not found for sickness absences.

The health effects of worktime control according to the occupational, family, and marital status are shown in tables 5 and 6 for the men and women, respectively. Among the men, low worktime control was not associated with self rated health or psychological distress, but it predicted sickness absence in two subgroups, with a 1.6-fold absence rate for those with children at home and a 2.6-fold rate for those with manual occupations (interaction with occupational status, $p=0.005)$. In the subgroups of women, low worktime control

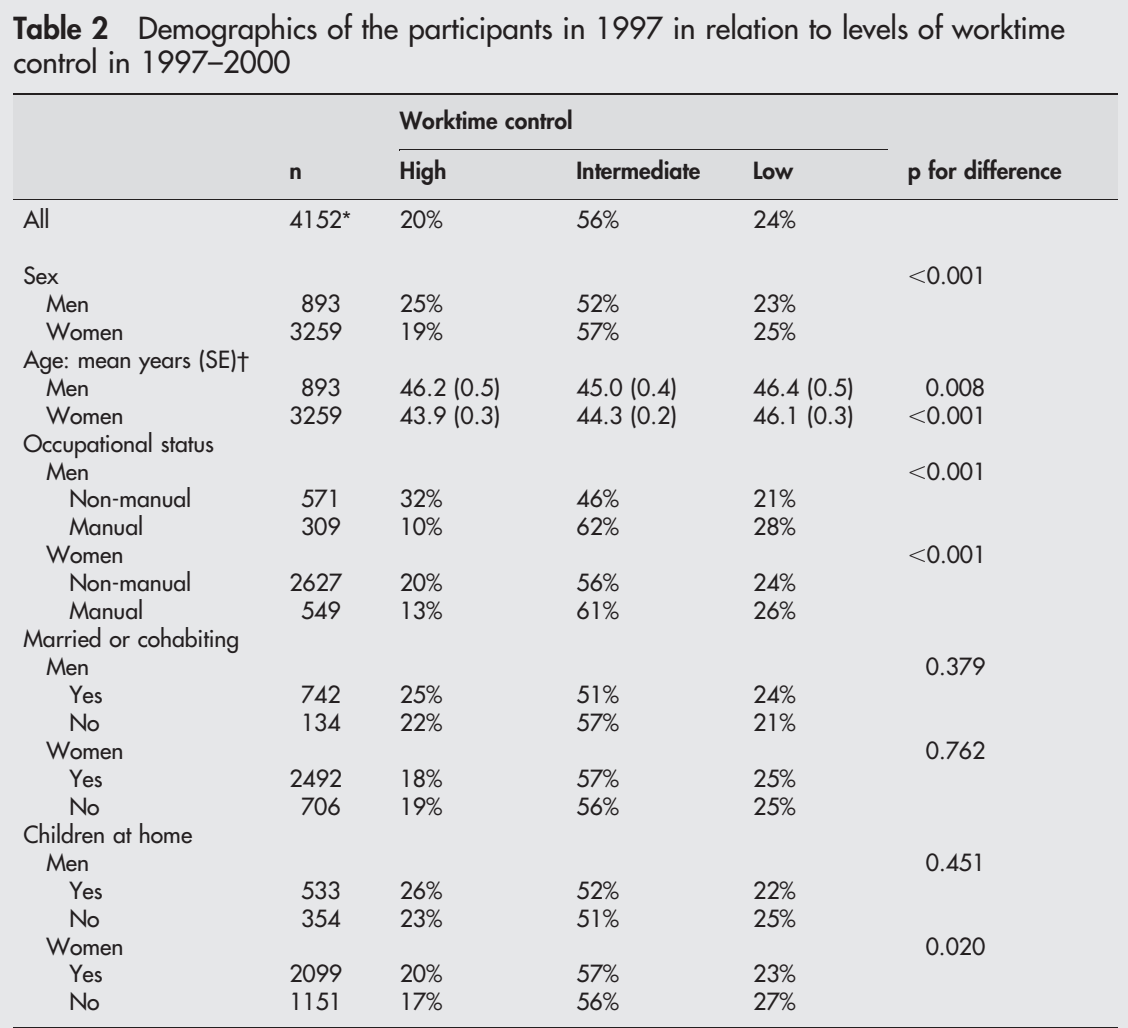

*Data on worktime control was missing for 66 participants. †Standard error. 
Table 3 Odds ratios $(95 \% \mathrm{Cl})$ for poor health and psychological distress and rate ratios $(95 \% \mathrm{Cl})$ of medically certified sickness absences at follow up by the levels of worktime control in 1997-2000

\begin{tabular}{|c|c|c|c|c|}
\hline \multirow[b]{2}{*}{ Worktime control $\dagger$} & \multicolumn{2}{|l|}{ Unadjusted } & \multicolumn{2}{|l|}{ Adjusted* } \\
\hline & Men & Women & Men & Women \\
\hline $\begin{array}{l}\text { High } \\
\text { Intermediate } \\
\text { Low } \\
\mathrm{p} \text { for interaction }\end{array}$ & $\begin{array}{l}\text { Self rated poor healtt } \\
1.00 \\
1.12(0.78 \text { to } 1.58) \\
1.33(0.89 \text { to } 1.99)\end{array}$ & $\begin{array}{l}1.00 \\
1.61(1.31 \text { to } 1.97) \\
2.01(1.59 \text { to } 2.53)\end{array}$ & $\begin{array}{l}1.00 \\
0.81(0.53 \text { to } 1.26) \\
0.93(0.56 \text { to } 1.56)\end{array}$ & $\begin{array}{l}1.00 \\
1.58 \text { (1.22 to } 2.03) \\
1.86 \text { (1.40 to } 2.48)\end{array}$ \\
\hline $\begin{array}{l}\text { High } \\
\text { Intermediate } \\
\text { Low } \\
\text { p for interaction }\end{array}$ & $\begin{array}{l}\text { Psychological distress } \\
1.00 \\
0.98(0.68 \text { to } 1.41) \\
0.88(0.57 \text { to } 1.35)\end{array}$ & $\begin{array}{l}1.00 \\
1.21 \text { (0.98 to } 1.49) \\
1.47(1.16 \text { to } 1.86)\end{array}$ & $\begin{array}{l}1.00 \\
1.09(0.73 \text { to } 1.64) \\
0.92(0.57 \text { to } 1.49)\end{array}$ & $\begin{array}{l}1.00 \\
1.18 \text { (0.93 to } 1.48) \\
1.40 \text { (1.08 to } 1.82)\end{array}$ \\
\hline $\begin{array}{l}\text { High } \\
\text { Intermediate } \\
\text { Low } \\
\text { p for interaction }\end{array}$ & $\begin{array}{l}\text { Sickness absence } \\
1.00 \\
1.26(1.01 \text { to } 1.59) \\
1.48(1.15 \text { to } 1.90)\end{array}$ & $\begin{array}{l}1.00 \\
1.38 \text { (1.23 to } 1.55) \\
1.46(1.29 \text { to } 1.66)\end{array}$ & $\begin{array}{l}1.00 \\
1.09(0.85 \text { to } 1.39) \\
1.28(0.97 \text { to } 1.68)\end{array}$ & $\begin{array}{l}1.00 \\
1.36(1.20 \text { to } 1.54) \\
1.51(1.31 \text { to } 1.73)\end{array}$ \\
\hline
\end{tabular}

*Adjusted for demographics (age, occupational status, marital status, dependent children), behavioural risk factors (smoking, alcohol consumption, body mass index, and sedentary lifestyle), and baseline level of the health outcome in question.

thevels of worktime control: high, highest tertile in both 1997 and 2000; low, lowest tertile in both 1997 and 2000; intermediate, all other combinations.

predicted health problems in both the manual and nonmanual occupations across all the outcomes-with the exception that psychological distress was not associated with worktime control among the female manual workers. In regard to marital status, worktime control consistently predicted health among the women with a spouse at home, but not among the single women (interaction with marital status on sickness absences, $\mathrm{p}=0.01$ ). In relation to family status, a low level of worktime control predicted poor health and sickness absence among both the women with and those without children at home and psychological distress among the women with children at home.

\section{DISCUSSION}

We found that low worktime control increased the risk of subsequent health problems, especially among women. The replicability of this result for three established health outcomes and for the initially healthy participants added to the plausibility of the finding. Reversed causality could not explain our results, as health status in the baseline was not associated with subsequent worktime control. Moreover, our figures may underestimate the true health effects, since a low degree of worktime control initially was associated with dropout from the study cohort.

In this study, the association between worktime control and health was most consistently found in the subgroups of married women and women with children at home (that is, in groups with many non-work responsibilities). It is noteworthy that a large body of evidence shows that combining paid work and family is associated with good health among women and that employed women with families have better health than housewives, a phenomenon referred to as the "multiple attachment" hypothesis. ${ }^{28}{ }^{29}$ Our data, restricted to full time employees only, produce tangent evidence of multiple roles being related to good health, as the single women had a $25 \%$ higher age adjusted risk of

Table 4 Initially healthy* versus initially unhealthy respondents: adjusted + odds ratios $(95 \% \mathrm{Cl})$ for poor health and psychological distress and rate ratios $(95 \% \mathrm{Cl})$ of medically certified sickness absences at follow up by the levels of worktime control in 1997-2000

\begin{tabular}{|c|c|c|c|c|}
\hline \multirow[b]{2}{*}{ Worktime controlt } & \multicolumn{2}{|l|}{ Initially healthy } & \multicolumn{2}{|l|}{ Initially unhealthy } \\
\hline & Men & Women & Men & Women \\
\hline $\begin{array}{l}\text { High } \\
\text { Intermediate } \\
\text { Low } \\
p \text { for interaction }\end{array}$ & $\begin{array}{l}\text { Self rated poor health } \\
1.00 \\
0.95(0.49 \text { to } 1.83) \\
0.97(0.51 \text { to } 1.83)\end{array}$ & $\begin{array}{l}1.00 \\
1.80(1.27 \text { to } 2.55) \\
1.87(1.31 \text { to } 2.68)\end{array}$ & $\begin{array}{l}1.00 \\
0.81(0.39 \text { to } 1.66) \\
0.85(0.36 \text { to } 1.99)\end{array}$ & $\begin{array}{l}1.00 \\
1.34(0.87 \text { to } 2.06) \\
1.98(1.20 \text { to } 3.25)\end{array}$ \\
\hline $\begin{array}{l}\text { High } \\
\text { Intermediate } \\
\text { Low } \\
p \text { for interaction }\end{array}$ & $\begin{array}{l}\text { Psychological distress } \\
1.00 \\
1.12(0.36 \text { to } 3.48) \\
1.27(0.49 \text { to } 3.32)\end{array}$ & $\begin{array}{l}1.00 \\
0.95(0.53 \text { to } 1.72) \\
1.91(1.22 \text { to } 3.01)\end{array}$ & $\begin{array}{l}1.00 \\
1.64(0.80 \text { to } 3.35) \\
1.46(0.65 \text { to } 3.28)\end{array}$ & $\begin{array}{l}1.00 \\
0.81(0.52 \text { to } 1.27) \\
1.11(0.68 \text { to } 1.82)\end{array}$ \\
\hline $\begin{array}{l}\text { High } \\
\text { Intermediate } \\
\text { Low } \\
\text { p for interaction }\end{array}$ & $\begin{array}{l}\text { Sickness absence } \\
1.00 \\
1.05(0.69 \text { to } 1.60) \\
1.26(0.86 \text { to } 1.86)\end{array}$ & $\begin{array}{l}1.00 \\
1.11(0.87 \text { to } 1.44) \\
1.32(1.06 \text { to } 1.64)\end{array}$ & $\begin{array}{l}1.00 \\
1.17(0.81 \text { to } 1.70) \\
1.41(0.93 \text { to } 2.14)\end{array}$ & $\begin{array}{l}1.00 \\
1.51(1.27 \text { to } 1.80) \\
1.76(1.45 \text { to } 2.13)\end{array}$ \\
\hline
\end{tabular}


Table 5 Subgroup analyses among the men: health status in the follow up by the levels of worktime control in 1997-2000, adjusted*

\begin{tabular}{|c|c|c|c|c|c|c|}
\hline \multirow[b]{2}{*}{$\begin{array}{l}\text { Worktime } \\
\text { controlt }\end{array}$} & \multicolumn{2}{|l|}{ Occupational status } & \multicolumn{2}{|l|}{ Marital status } & \multicolumn{2}{|l|}{ Family status } \\
\hline & $\begin{array}{l}\text { Non-manual } \\
\text { workers }(n=575)\end{array}$ & $\begin{array}{l}\text { Manual workers } \\
(\mathrm{n}=314)\end{array}$ & $\begin{array}{l}\text { Single/separated/ } \\
\text { widowed }(n=136)\end{array}$ & $\begin{array}{l}\text { Married or } \\
\text { cohabiting ( } n=750)\end{array}$ & $\begin{array}{l}\text { No children at } \\
\text { home }(n=358)\end{array}$ & $\begin{array}{l}\text { Children at } \\
\text { home }(n=538)\end{array}$ \\
\hline $\begin{array}{l}\text { High } \\
\text { Intermediate } \\
\text { Low } \\
p \text { for interaction }\end{array}$ & $\begin{array}{l}\text { Self rated poor health } \\
1.00 \\
0.77(0.48 \text { to } 1.25) \\
0.84(0.47 \text { to } 1.52) \\
0.367\end{array}$ & $\begin{array}{l}1.00 \\
1.17(0.41 \text { to } 3.39) \\
1.33(0.42 \text { to } 4.18)\end{array}$ & $\begin{array}{l}1.00 \\
1.47(0.34 \text { to } 6.41) \\
5.37(0.93 \text { to } 30.9) \\
0.123\end{array}$ & $\begin{array}{l}1.00 \\
0.78(0.49 \text { to } 1.23) \\
0.80(0.46 \text { to } 1.37)\end{array}$ & $\begin{array}{l}1.00 \\
0.44(0.21 \text { to } 0.90) \\
1.75(0.33 \text { to } 1.72) \\
0.493\end{array}$ & $\begin{array}{l}1.00 \\
1.20(0.68 \text { to } 2.12) \\
1.08(0.55 \text { to } 2.10)\end{array}$ \\
\hline $\begin{array}{l}\text { High } \\
\text { Intermediate } \\
\text { Low } \\
\text { p for interaction }\end{array}$ & $\begin{array}{l}\text { Psychological distress } \\
1.00 \\
1.07(0.68 \text { to } 1.67) \\
0.73(0.41 \text { to } 1.30) \\
0.215\end{array}$ & $\begin{array}{l}1.00 \\
1.56(0.56 \text { to } 4.37) \\
1.63(0.54 \text { to } 4.88)\end{array}$ & $\begin{array}{l}1.00 \\
0.99(0.32 \text { to } 3.08) \\
2.54(0.68 \text { to } 9.51) \\
0.165\end{array}$ & $\begin{array}{l}1.00 \\
1.13(0.73 \text { to } 1.75) \\
0.79(0.46 \text { to } 1.33)\end{array}$ & $\begin{array}{l}1.00 \\
0.70(0.37 \text { to } 1.37) \\
0.79(0.37 \text { to } 1.68) \\
0.930\end{array}$ & $\begin{array}{l}1.00 \\
1.42(0.84 \text { to } 2.40) \\
0.97(0.51 \text { to } 1.83)\end{array}$ \\
\hline $\begin{array}{l}\text { High } \\
\text { Intermediate } \\
\text { Low } \\
\text { p for interaction }\end{array}$ & $\begin{array}{l}\text { Sickness absence } \S \\
1.00 \\
0.86(0.65 \text { to } 1.15) \\
1.10(0.78 \text { to } 1.54) \\
0.005\end{array}$ & $\begin{array}{l}1.00 \\
2.07(1.14 \text { to } 3.75) \\
2.61(1.41 \text { to } 4.83)\end{array}$ & $\begin{array}{l}1.00 \\
1.98(0.91 \text { to } 4.30) \\
2.16(0.91 \text { to } 5.10) \\
0.236\end{array}$ & $\begin{array}{l}1.00 \\
0.99(0.76 \text { to } 1.29) \\
1.24(0.93 \text { to } 1.66)\end{array}$ & $\begin{array}{l}1.00 \\
0.99(0.68 \text { to } 1.44) \\
0.93(0.59 \text { to } 1.46) \\
0.082\end{array}$ & $\begin{array}{l}1.00 \\
1.14(0.82 \text { to } 1.57) \\
1.62(1.14 \text { to } 2.29)\end{array}$ \\
\hline
\end{tabular}

*Adjusted for age, baseline level of the health outcome in question, and behavioural risk factors (smoking, alcohol consumption, body mass index, and sedentary lifestyle) in all cases, and for occupational status, marital status, and dependent children where appropriate.

tLevels of worktime control: high, highest tertile in both 1997 and 2000; low, lowest tertile in both 1997 and 2000; intermediate, all other combinations. †Odds ratio $(95 \% \mathrm{Cl})$.

§ate ratio $(95 \% \mathrm{Cl})$.

medically certified sickness absences than the women with a spouse, and as the corresponding risk was $11 \%$ higher for the women without dependent children than it was for those with children at home (tables not shown). However, our results agree with the prior evidence on the "double burden" of paid and unpaid work $\mathrm{k}^{30-32}$ and its effects on health, ${ }^{33}$ evidence that complements the "multiple attachment" literature in terms of understanding working women's health. Women are responsible for a greater number of duties at home, and characteristically for duties taken care of daily, often at a fixed time (for example, cooking), whereas there is more temporal flexibility in men's duties (for example, managing finances, household maintenance). ${ }^{30-33}$ The advantages of a high level of worktime control with respect to juggling occupational demands and private responsibilities may explain why high worktime control seems more relevant as a buffer against health problems among women than among men. In line with this explanation, a prior cross sectional study has linked family supportive organizational policies, such as flexible scheduling, with lower levels of perceived work-home conflict and strain. ${ }^{34}$

In an earlier cross sectional study, we found that the gender differences in the associations between worktime control and health were replicable within a single occupation. ${ }^{14}$ Therefore, the importance of worktime control for women's health appeared to be attributable to the gender differences in unpaid work load rather than to confounding due to the differences in paid work characteristics and occupational distribution. In our present study, the health

Table 6 Subgroup analyses among the women: health status in the follow up by the levels of worktime control in 1997-2000, adjusted $^{*}$

\begin{tabular}{|c|c|c|c|c|c|c|}
\hline \multirow[b]{2}{*}{ Worktime controlt } & \multicolumn{2}{|l|}{ Occupational status } & \multicolumn{2}{|l|}{ Marital status } & \multicolumn{2}{|l|}{ Family status } \\
\hline & $\begin{array}{l}\text { Non-manual } \\
\text { workers }(n=2669)\end{array}$ & $\begin{array}{l}\text { Manual workers } \\
(n=561)\end{array}$ & $\begin{array}{l}\text { Single/separated/ } \\
\text { widowed }(n=719)\end{array}$ & $\begin{array}{l}\text { Married or } \\
\text { cohabiting }(n=2528)\end{array}$ & $\begin{array}{l}\text { No children at } \\
\text { home }(n=1182)\end{array}$ & $\begin{array}{l}\text { Children at } \\
\text { home ( } n=2123 \text { ) }\end{array}$ \\
\hline & \multicolumn{6}{|c|}{ Self rated poor health $\ddagger$} \\
\hline High & 1.00 & 1.00 & 1.00 & 1.00 & 1.00 & 1.00 \\
\hline Intermediate & 1.48 (1.13 to 1.94$)$ & 2.55 (1.24 to 5.27$)$ & 1.53 (0.90 to 2.59$)$ & 1.59 (1.19 to 2.12$)$ & $1.87(1.21$ to 2.90$)$ & 1.44 (1.06 to 1.97$)$ \\
\hline Low & 1.68 (1.24 to 2.29$)$ & $3.54(1.61$ to 7.80$)$ & 1.53 (0.84 to 2.79$)$ & $1.96(1.42$ to 2.71$)$ & 2.28 (1.40 to 3.72$)$ & $1.66(1.17$ to 2.36$)$ \\
\hline \multirow[t]{2}{*}{$p$ for interaction } & 0.091 & & 0.360 & & 0.452 & \\
\hline & \multicolumn{6}{|c|}{ Psychological distress $\ddagger$} \\
\hline High & 1.00 & 1.00 & 1.00 & 1.00 & 1.00 & 1.00 \\
\hline Intermediate & $1.13(0.88$ to 1.44$)$ & 1.70 (0.83 to 3.48$)$ & $0.93(0.57$ to 1.51$)$ & 1.26 (0.97 to 1.64$)$ & $1.13(0.75$ to 1.70$)$ & $1.22(0.92$ to 1.61$)$ \\
\hline & 1.43 (1.08 to 1.88$)$ & $1.38(0.62$ to 3.07$)$ & $1.47(0.85$ to 2.56$)$ & 1.40 (1.04 to 1.89$)$ & 1.29 (0.82 to 2.03$)$ & 1.45 (1.05 to 2.01$)$ \\
\hline \multirow[t]{2}{*}{$p$ for interaction } & 0.696 & & 0.612 & & 0.882 & \\
\hline & \multicolumn{6}{|l|}{ Sickness absence $\S$} \\
\hline High & 1.00 & 1.00 & 1.00 & 1.00 & 1.00 & 1.00 \\
\hline Intermediate & 1.29 (1.13 to 1.48$)$ & $1.59(1.16$ to 2.16$)$ & $1.15(0.92$ to 1.45$)$ & 1.41 (1.22 to 1.63$)$ & 1.29 (1.05 to 1.60$)$ & 1.35 (1.16 to 1.57$)$ \\
\hline Low & 1.36 (1.17 to 1.58$)$ & 1.91 (1.37 to 2.66$)$ & $1.13(0.87$ to 1.47$)$ & 1.59 (1.36 to 1.87$)$ & 1.38 (1.10 to 1.74$)$ & 1.49 (1.26 to 1.76$)$ \\
\hline$p$ for interaction & 0.060 & & 0.010 & & 0.622 & \\
\hline \multicolumn{7}{|c|}{$\begin{array}{l}\text { *Adjusted for age, baseline level of the health outcome in question, and behavioural risk factors (smoking, alcohol consumption, body mass index, and sedentary } \\
\text { lifestyle) in all cases, and for occupational status, marital status, and dependent children where appropriate. } \\
\text { †Levels of worktime control: high, highest tertile in both } 1997 \text { and } 2000 \text {; low, lowest tertile in both } 1997 \text { and } 2000 \text {; intermediate, all other combinations. } \\
\text { †Odds ratio }(95 \% \mathrm{CI}) \text {. } \\
\text { §Rate ratio }(95 \% \mathrm{Cl}) \text {. }\end{array}$} \\
\hline
\end{tabular}


effects of worktime control were slightly stronger among the manual workers than among the non-manual workers. Manual workers may have fewer opportunities to obtain paid help to cover non-work responsibilities, and the successful handling of the work-non-work interface may rely more on their own activities. These circumstances further emphasise the importance of the optimal timing of work hours. Interestingly, the generally positive health associations of combining paid work with family have in some studies been lacking in the lower positions of the occupational hierarchy, ${ }^{28}$ which has similarly been suggested to originate from less financial resources to ease the burdens of unpaid work.

Methodologically, the strengths of this study include its prospective design in a large sample, the control for baseline health status and several potential confounders, the follow up of sample attrition, and the use of both register based and self reported health outcomes. The men were outnumbered by the women, and this difference in the numbers may have led to the lack of statistical significance in the main results among the men, although we found subgroups of men where worktime control and sickness absences were related. Nevertheless, the interaction analyses offered some support for a gender difference in the importance of this control element. For further evidence of the link between worktime control and health, studies using objective measures of worktime control (in addition to self reports) as well as intervention studies should be carried out.

With respect to work life, we observed a significant declining trend in worktime control over time. This finding was in line with observations from repeated surveys on European working conditions that show declining trends in perceived control over breaks and holidays, as well as an increasing intensity of work life. ${ }^{32}$ Worktime is in transition in Western societies. There are major trends towards work hours being differentiated, individualised, and made more flexible. ${ }^{35}$ In light of our results, these trends present both promising and threatening prospects for employee health, depending on the extent of worktime control given to employees.

For policy makers, providing employees with worktime control is an issue of organisational ergonomics, defined as the design of work processes and organisational policies compatible with the needs, abilities, and limitations of people. ${ }^{36}$ From the point of view of organisations, our results also indicate that providing employees with worktime control can save considerable costs through fewer sickness absences. The fact that three quarters of the employees in the municipal sector now studied are female further emphasises the practical implications of our results.

In conclusion, low control over worktime appears to be a health risk for female employees, especially for those with families, and for manual workers. The results underline the importance of extending occupational health research on the various dimensions of control, and also the significance of taking conditions at home into account when wellbeing at work is analysed.

\section{ACKNOWLEDGEMENTS}

This study was supported by the Academy of Finland (project no. 77560), the Finnish Work Environment Foundation (project no. 101190), The Finnish Local Government Pensions Institution, and the participating towns.

\section{Authors' affiliations}

L Ala-Mursula, Development and Service Centre of Occupational Health, City of Oulu, Finland; Department of Public Health Science and General Practice, University of Oulu, Finland
J Vahtera, J Pentti, M Kivimäki, Finnish Institute of Occupational Health, Finland

Conflicts of interest: none

\section{REFERENCES}

1 North F, Syme SL, Feeney A, et al. Psychosocial work environment and sickness absence among British civil servants: The Whitehall II study. Am J Public Health 1996;86:332-40.

2 Marmot MG, Bosma H, Hemingway $\mathrm{H}$, et al. Contribution of job control and other risk factors to social variations in coronary heart disease incidence. Lancet 1997;350:235-9.

3 Kivimäki M, Vahtera J, Thomson L, et al. Psychosocial factors predicting employee sickness absence during economic decline. J Appl Psychol 1997:82:858-72.

4 Stansfeld SA, Fuhrer R, Shipley MJ, et al. Work characteristics predict psychiatric morbidity: prospective results from the Whitehall II study. Occup Environ Med 1999;56:302-7.

5 Vahtera J, Kivimäki M, Pentti J, et al. Effect of change in the psychosocial work environment on sickness absence: a 7-year follow-up of initially healthy employees. J Epidemiol Community Health 2000;54:484-93.

6 Cheng Y, Kawachi I, Coakley EH, et al. Association between psychosocial work characteristics and health functioning in American women: prospective study. BMJ 2000;320:1432-6

7 Kivimäki M, Leino-Arjas $P$, Luukkonen $R$, et al. Work stress and risk of cardiovascular mortality: prospective cohort study of industrial employees. BMJ 2002;325:857-61.

8 Ganster DC. Improving measures of worker control in occupational stress research. In: Hurrell JJ Jr, Murphy LR, Sauter SL, et al. Occupational stress: issues and developments in research. Philadelphia, PA: Taylor and Francis, 1988:88-99.

9 Frese M. Theoretical models of control and health. In: Sauter SL, Hurrell JA, Cooper CL, eds. Job control and worker health. Chichester: John Wiley \& Sons Ltd, 1989:107-28.

10 Knauth P. Innovative worktime arrangements. Scand J Work Environ Health 1998;24(suppl 3):13-17.

11 Baltes B, Briggs TE, Huff JW, et al. Flexible and compressed workweek schedules: a meta-analysis of their effects on work-related criteria. J Appl Psychol 1999;84:496-513.

12 Alfredsson L, Spetz C-L, Theorell T. Type of occupation and near-future hospitalization for myocardial infarction and some other diagnoses. Int J Epidemiol 1985; 14:378-88

13 Hammar N, Alfredsson L, Theorell T. Job characteristics and the incidence of myocardial infarction. Int J Epidemiol 1994;23:277-84.

14 Ala-Mursula L, Vahtera J, Kivimäki M, et al. Employee control over working times: associations with subjective health and sickness absences. J Epidemiol Community Health 2002;56:272-8.

15 Vahtera J, Kivimäki M, Pentti J. The role of extended weekends in sickness absenteeism. Occup Environ Med 2001:58:818-22.

16 Idler EL, Angel RJ. Self-rated health and mortality in the NHANES-I epidemiologic follow-up study. Am J Public Health 1990;80:446-52.

17 Kaplan GA, Goldberg DE, Everson SA, et al. Perceived health status and morbidity and mortality: evidence from the Kuopio ischemic heart disease risk factor study. Int J Epidemiol 1996;25:259-65.

18 Miilunpalo S, Vuori I, Oja P, et al. Self-rated health status as a health measure: the predictive value of self-reported health status on the use of physician services and on mortality in the working-age population. J Clin Epidemiol 1997:50:517-28.

19 Goldberg D, Williams P. A user's guide to the General Health Questionnaire. Berkshire: NFER-Nelson Publishing Co, 1988.

20 Goldberg DP, Gater R, Sartorius N, et al. The validity of the two versions of the GHQ in the WHO study of mental illness in general health care. Psychological Medicine 1997;27:191-7.

21 Marmot M, Feeney A, Shipley $M$, et al. Sickness absence as a measure of health status and functioning: from the UK Whitehall II study. J Epidemiol Community Health 1995;49:124-30.

22 Vahtera J, Kivimäki M, Pentti J. Effect of organisational downsizing on health of employees. Lancet 1997;350:1124-8.

23 Statistics Finland. Classification of occupations. Handbook no. 14. Helsinki: Statistics Finland, 1987.

24 Vahtera J, Poikolainen K, Kivimäki $M$, et al. Alcohol intake and sickness absence: a curvilinear relation. Am J Epidemiol 2002;156:969-76.

25 Rimm EB, Williams P, Fosher K, et al. Moderate alcohol intake and lower risk of coronary heart disease: meta-analysis of effects on lipids and haemostatic factors. BMJ 1999:319:1523-8.

26 Kujala UM, Kaprio J, Sarna S, et al. Relationship of leisure-time physical activity and mortality. The Finnish twin cohort. JAMA 1998;279:440-4.

27 SAS/STAT Software, release 8.2. Cary, NC: SAS Institute Inc, 2001.

28 Khlat M, Sermet C, Le Pape A. Women's health in relation with their family and work roles: France in the early 1990s. Soc Sci Med 2000;50:1807-25.

29 Lahelma E, Arber S, Kivelä K, et al. Multiple roles and health among British and Finnish women: the influence of socioeconomic circumstances. Soc Sci Med 2002:54:727-40.

30 Wortman C, Biernat $M$, Lang E. Coping with role overload. In: Frankenhaeuser M, Lundberg U, Chesney M, eds. Women, work and health. Stress and opportunities. New York: Plenum Press, 1991:85-110.

31 Lundberg U, Mårdberg B, Frankenhaeuser M. The total workload of male and female white collar workers as related to age, occupational level, and number of children. Scand J Psychol 1994;35:315-27. 
32 Paoli P, Merllié D. Third European survey on working conditions 2000 Luxembourg: European Foundation for the Improvement of Living and Working Conditions, Office for Official Publications of the European Communities, 2001.

33 Frankenhaeuser $M$. The psychophysiology of sex differences as related to occupational status. In: Frankenhaeuser M, Lundberg U, Chesney M, eds. Women, work and health. Stress and opportunities. New York: Plenum Press, 1991:39-61.
34 Thomas LT Ganster DC. Impact of family-supportive work variables on workfamily conflict and strain: a control perspective. J Appl Psychol 1995;80:6-15.

35 Julkunen R, Nätti J. The modernization of working times: flexibility and work sharing in Finland. Jyväskylä, Finland: SoPhi, University of Jyväskylä, 1999.

36 Website of the International Association of Ergonomics (IEA): http:// www.iea.cc/ergonomics/. 